\title{
PENGARUH SISTEM PEMBELAJARAN DAN KEPUASAN KERJA DOSEN TERHADAP KINERJA DOSEN DI STIKES KARSA HUSADA GARUT
}

\author{
EtiSuliyawati \\ STIKes Karsa Husada Garut \\ stikeskarsahusada@yahoo.com
}

\begin{abstract}
Central issue in this study is teacher performance is not optimal, the researchers observed due to learning and job satisfaction of teachers who have not been going well. On the basis of thought and consideration, the researchers wanted to investigate further in the form of research thesis entitled "Effect of learning and teachers' job satisfaction on the performance of teachers in STIKes Karsa Husada Garut." The method used is explanatory survey method, ie a method that aims to test the hypothesis that has been formulated previously. Technical analysis is a statistical technique that serves to classify descriptive data, work, conclude, explain and present the processed results. It aims to make the pattern a causal relationship between the value of a variable to another variable. Analysis of the data processing using path analysis (Path analisys). The results showed that the performance of teachers affected by the learning system variables and job satisfaction of teachers, either partially or simultaneously. Partially influenced by the variable performance of teachers learning system by 47,2\%, and influenced by teachers' job satisfaction variables of $18,8 \%$, and the rest is influenced by other variables. The conclusion of this research is learning and teacher job satisfaction has been empirically to give effect to the performance of teachers in STIKes Karsa Husada Garut, either partially or simultaneously. The results also found that teacher performance is also influenced by other factors academically recognized.
\end{abstract}

Keywords: Instructional System, Satisfaction Teaching, Teaching Job

\section{A. PENDAhULUAN}

Tertuang pada rencana strategis Kementrian Pendidikan dan Kebudayaan Republik Indonesia menghendaki terwujudnya Sistem Pendidikan sebagai pranata sosial yang kuat dan berwibawa untuk memberdayakan semua warga negara Indonesia agar berkembang menjadi manusia yang berkualitas sehingga mampu dan proaktif menjawab tantangan zaman yang selalu berubah. Sejalan dengan visi tersebut, Kementrian Pendidikan dan Kebudayaan Republik Indonesia bertekad menghasilkan manusia Indonesia yang cerdas secara spiritual, emosional, sosial, intelektual, dan kinestetis serta mampu menghadapi persaingan yang semakin ketat dengan bangsa lain.
Pendidikan bermutu merupakan investasi masa depan bangsa dalam membentuk warga negara seutuhnya yang terdidik, cerdas, dan merupakan asset yang menentukan eksistensi serta kemajuan bangsa dalam berbagai dimensi kehidupan. Proses pengembangan manusia yang terdidik dan cerdas memerlukan pendidik yang mampu mengembangkan potensi peserta didik melalui olah qolbu, olah fikir, olah karsa, olah karya, olah rasa, dan olah raga (pendidik professional).

Profesi dosen bukan sekedar wahana untuk menyalurkan hobi ataupun sebagai pekerjaan sambilan, akan tetapi merupakan pekerjaan yang harus ditekuni untuk mewujudkan keahlian profesional secara maksimal. Sebagai tenaga profesional, dosen memegang 
peranan dan tanggung jawab yang penting dalam pelaksanaan program pembelajaran di kampus. Selain itu, dosen juga memiliki tanggung jawab atas ketercapaian tujuan pembelajaran di kampus. Dalam meningkatkan pendidikan harus memperhatikan komponen-komponen pendidikan, seperti yang dinyatakan Umar dan La Sulo (2005:60-61) menyatakan sejumlah komponen pendidikan yaitu masukan mentah (raw input) yaitu mahasiswa yang akan diproses menjadi tamatan (output), masukan instrumental (instrumental input) berupa dosen, administrasi kampus, kurikulum, anggaran pendidikan, prasarana dan sarana dan masukan lingkungan (environmental input). Komponen-komponen pendidikan tersebut memiliki peran penting. Salah satu peran penting ada pada dosen, karena merupakan ujung tombak dalam proses pembelajaran. Dosen menduduki posisi yang sangat strategis yang akan memberikan kontribusi langsung terhadap kualitas hasil belajar mahasiswa. Seperti yang dinyatakan Aqib (2002:22) bahwa dosen adalah faktor penentu bagi keberhasilan pendidikan di kampus, karena dosen merupakan sentral serta sumber kegiatan belajar mengajar. Lebih lanjut dinyatakan Djamarah (2002:32) bahwa dosen merupakan komponen yang berpengaruh dalam peningkatan mutu pendidikan di kampus.

Menurut Suparlan (2005), upaya peningkatan mutu pendidik dan tenaga kependidikan tidak dapat dilepaskan dengan aspek-aspek penting sebagai berikut, yaitu gaji dan standar kesejahteraan yang layak untuk kehidupan, standar kualifikasi, standar kompetensi dan upaya peningkatannya, sistem sertifikasi pendidik dan tenaga kependidikan dan alih profesi yang tidak memenuhi standar kompetensi, seleksi yang jujur dan transparan, standar pembinaan karir, penyiapan calon pendidikdan tenaga kependidikan yang selaras dengan standar kompetensi, dan lebih menekankan praktik mengajar dari pada teori semata-mata, sistem diklat di lembaga in service training dan pendidikan profesi, on the job training
(OTJ) di kampus, dan (9) pemberdayaan organisasi pembinaan professional.

Agar kinerja dosen meningkat perlu diberi peluang atau kesempatan dalam mengembangkan segenap potensinya misalnya melalui peningkatan pendidikan, diikutsertakan dalam kegiatan seminar, loka karya, serta pendidikan dan pelatihan lainnya. Melalui kegiatan-kegiatan tersebut diharapkan kinerja dosen akan meningkat dengan semakin baiknya pelaksanaan kegiatan belajar mengajar, termasuk juga kemampuan memanfaatkan teknologi informasi untuk kepentingan pembelajaran. Bila diamati di lapangan, tampak sebagian dosen sudah menunjukkan kinerja baik dalam menjalankan tugas dan fungsinya, artinya sesuai dengan tugas pokok dan fungsi dosen seperti: melaksanakan kegiatan dalam membuat program pengajaran, melaksanakan kegiatan pembelajaran, melaksanakan penilaian, melaksanakan test harian, menyusun dan melaksanakan program perbaikan dan pengayaan dan mengadakan pengembangan bidang pengajaran yang menjadi tanggung jawabnya. Akan tetapi masih ada sebagian kinerja dosen yang rendah antara lain: dosen mengajar tanpa persiapan yang matang atau sekedar menyampaikan materi ajar dan mengajar secara monoton selain itu fenomena bahwa sebagian dosen mengajar hanya sebagai rutinitas dan tanpa adanya inovasi dalam pembelajaran. Metode yang digunakan dalam mengajar masih banyak menggunakan metode ceramah, mencatat, dan kurang menggali kreativitas mahasiswa. Sementara persiapan mengajar yang berupa rencana pelaksanaan pembelajaran hanya sebagai formalitas administrasi bahkan ada juga dosen yang tidak membuat administrasi perangkat pembelajaran sebagai bahan persiapan untuk mengajar. Fenomena lain yang di dapat dalam penelitian pendahuluan berkenaan dengan kualifikasi akademik yang dimiliki 
dosen - dosen, dari data yang diambil dari kepegawaian tenaga dosen tetap STIKes Karsa Husada Garut tahun 2015 tercatat 94\% dosen STIKes Karsa Husada Garut yang belum memenuhi standar kualifikasi akademik, dalam artian belum sertifikasi dosen. Selain itu apabila dilihat dari hasil uji kompetensi, selama dua tahun terahir ini STIKes Karsa Husada Garut belum mencapai target kelulusan $100 \%$. Keadaan ini terkait dengan kualitas kinerja dosen STIKes Karsa Husada Garut, karena kinerja dosen sangat berpengaruh dalam proses pendidikan di kampus/institusi. Rendahnya kinerja dosen dapat berpengaruh pada kualitas pendidikan menjadi rendah pula.

\section{Tabel 1}

Jumlah Dosen Berdasarkan Tingkat Pendidikan STIKes Karsa Husada Garut

\begin{tabular}{|c|c|c|c|}
\hline Von. & I'inglat Pendidikail & I I ainlàli & Peractatase \\
\hline $\begin{array}{l}1 \\
7\end{array}$ & 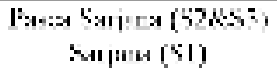 & $3 n$ & $\begin{array}{l}\text { ans: } \\
\text { ans: }\end{array}$ \\
\hline & J.mlnì & $5 \overline{0}$ & 1606 \\
\hline
\end{tabular}

Tabel 2

Jumlah Dosen Berdasarkan Keahlian STIKes Karsa Husada Garut

\begin{tabular}{|c|c|c|c|}
\hline Yo. & Keuhllan & Juislnh & Persentuses \\
\hline 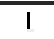 & 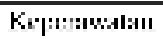 & 77 & $54 \%$ \\
\hline 2 & Kelmilnizu & 14 & 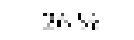 \\
\hline a & as & 3 & $\therefore s i$ \\
\hline 4 & Pendidismin & 3 & $\therefore s i$ \\
\hline 5 & Ton & 4 & $s: f$ \\
\hline & J. & $5 n$ & $\cos s$ \\
\hline
\end{tabular}

Kualitas pendidikan yang baik akan terwujud apabila dilaksanakan oleh dosen dosen yang profesional atau dosen yang kinerjanya baik. Selain faktor yang menunjang dosen untuk bekerja (kinerja) yang baik selain professional, kesejahteraan dosen dan kepuasan kerja. Artinya dosen merasa puas atas perilaku organisasi dan dipenuhi semua hak-haknya, maka diharapkan akan bekerja dengan penuh semangat dan tanggung jawab. Dalam UU SisDiknas Nomor 20 Tahun 2003, disebutkan bahwa pendidik berhak memperoleh penghasilan dan jaminan kesejahteraan sosial yang pantas dan memadai, serta penghargaan sesuai dengan tugas dan prestasi kerja. Kepuasan kerja merupakan salah satu faktor penting untuk mendapatkan hasil kerja yang optimal. Menurut Siagian (2003:297) kepuasan kerja dapat memacu prestasi kerja yang lebih baik. Oleh karena itu ketika seseorang merasakan kepuasan dalam bekerja tentunya ia akan berupaya semaksimal mungkin dengan segenap kemampuan yang dimilikinya untuk menyelesaikan tugas pekerjaannya. Olehkarena itu, menurut Vroom menyatakan bahwa kepuasan kerja merupakan penilaian dari pekerja yaitu seberapa jauh pekerjaannya secara keseluruhan memuaskan kebutuhannya (As'ad, 2001:104). Berbagai hasil penelitian yang dilakukan oleh para ahli menunjukkan bahwa faktor utama ketidak puasan kerja adalah kompensasi yang tidak sesuai dengan harapan. Di samping itu adanya ketidakpuasan terhadap kompensasi yang diterima dapat menimbulkan perilaku negatif yang bisa dilihat dari menurunnya komitmen yang pada ahirnya akan menurunkan prestasi kerjanya (Noe, 1994:135). Kepuasan kerja dosen merupakan sasaran penting dalam manajemen sumber daya manusia, karena secara langsung maupun tidak langsung akan mempengaruhi produktivitas kerja. Suatu gejala yang dapat membuat kurang baiknya kondisi organisasi kampus adalah rendahnya kepuasan kerja dosen. Fenomena yang ada di STIKes Karsa Husada Garut sesuai dengan penelitian pendahuluan dengan beberapa dosen di STIKes Karsa Husada Garut, terdapat permasalahan ketidakpuasan dosen, kinerja dosen masih banyak menghadapi kendala. Beberapa kendala itu dapat dilihat dari hal-hal berikut ini:

1. Ketidakpuasan dosen dalam bentuk meningkatnya keinginan mendapatkan penghasilan yang lebih 
banyak. Penghasilan yang lebih layak, dalam hal ini sesuai dengan standar kebutuhan hidup yang layak;

2. Tingkat kesejahteraan dosen kurang memadai;

3. Pendapatan dosen secara umum masih sangat memprihatinkan;

4. Sarana dan prasarana ruangan dan laboratorium sangat terbatas. Hal ini berpengaruh pada proses pembelajaran yang dikelola oleh para dosen, dan pada gilirannya berpengaruh pula pada kualitas hasil belajar para mahasiswa;

5. Motivasi kerja dosen rendah;

6. Persepsi atas perannya sebagai pendidik dengan segala tugas dan pekerjaannya dirasakan sebagai hal yang sangat penting; dan

7. Kinerja dosen masih rendah.

Pelaksanaan wewenang dan tanggung jawab dosen belum seimbang. Berbagai kewajiban para dosen secara umum sudah ditunaikan. Adapun kewenangannya masih belum sepenuhnya dapat dinikmati para dosen. Beberapa contoh mengenai kewenangan yang Salah satu pendekatan yang dapat digunakan untuk menentukan kualitas proses pendidikan menurut Wina Sanjaya (2008:195) adalah pendekatan sistem. Melalui pendekatan sistem dapat melihat berbagai aspek yang dapat mempengaruhi keberhasilan suatu proses. Sistem adalah satu kesatuan komponen yang satu sama lain saling berkaitan dan saling berinteraksi untuk mencapai suatu hasil yang diharapkan secara optimal sesuai dengan tujuan yang telah diharapkan.

Berdasarkan pengertian di atas, maka ada tiga hal penting yang menjadi karakteristik suatu sistem. Pertama, setiap sistem pasti memiliki tujuan.Tujuan merupakan ciri utama suatu sistem.Tak ada sistem tanpa tujuan.Tujuan merupakan arah yang harus dicapai oleh suatu pergerakan sistem. Kedua, sistem selalu mengandung suatu proses. Proses adalah rangkaian kegiatan. Kegiatan diarahkan untuk mencapai tujuan. Semakin kompleks tujuan, maka semakin rumit juga proses kegiatan. Ketiga, proses kegiatan dalam suatu sistem selalu melibatkan dan memanfaatkan berbagai komponen atau unsur-unsur tertentu. Oleh sebab itu, suatu sistem tidak mungkin hanya memiliki satu komponen saja. Sistem memerlukan dukungan berbagai komponen yang satu sama lain saling berkaitan.

\section{B. KAJIAN LITERATUR}

1. Kepuasan Kerja Dosen

Kepuasan kerja merupakan hal penting bagi setiap pekerja. Setiap pekerja memiliki karakteristik berbeda-beda, maka tingkat kepuasan kerjanya pun berbedabeda pula. Tinggi rendahnya kepuasan kerja tersebut dapat memberikan dampak yang tidak sama. Hal itu sangat tergantung pada sikap mental individu yang bersangkutan sebagaimana Roe dan Byars (1992: 367-368) mengatakan bahwa: Job satisfaction refers to individuals mentals set may be positif or negatif, depending on individual mental set concerning the major components of job satisfaction. Kepuasan kerja yang tinggi sangat memungkinkan untuk mendorong terwujudnya tujuan suatu lembaga atau perusahaan. Sementara tingkat kepuasan kerja yang rendah merupakan ancaman yang akan membawa kehancuran lembaga atau perusahaan segera maupun secara perlahan.

Banyak sekali teori-teori tentang kepuasan kerja yang dibahas para ahli, akan tetapi teori-teori yang berkenaan dengan kepentingan pembahasan dalam bab ini lebih menekankan kepada, teori perbedaan (Discrepancy Theory), teori keseimbangan (Equity Theory), teori dua faktor (Two Factor Theory), dan teori pengharapan (Expectancey Theory).

2. Kinerja Dosen 
Kinerja anggota suatu organisasi sangat besar pengaruhnya bagi tercapai atau tidaknya tujuan organisasi tersebut. Oleh karena itu baik tidaknya organisasi sangat bergantung kepada bagaimana para anggota organisasi tersebut mampu melaksanakan tugasnya sesuai dengan tanggung jawab yang dibebankan kepadanya. Kualitas kerja anggota suatu organisasi dilandasi oleh sikap pengetahuan dan keterampilan seseorang dalam melaksanakan tugas yang menjadi tanggung jawabnya. Kata kinerja atau prestasi kerja berasal dari kata "performance" yang menurut Mangkunegara (2005:67) diartikan sebagai prestasi kerja sesungguhnya yang dicapai seseorang. Sehingga kineja dapat diartikan sebagai hasil kerja yangdapat dilihat secara kuantitas dan kualitas yang dicapai seseorang dalam melaksanakan tugas sesuai dengan tanggung jawab yang diberikan kepadanya.

Faktor-faktor Yang Mempengaruhi Kinerja Dosen, Menurut Panji (1998:14) dijelaskan bahwa kinerja seseorang dipengaruhi oleh beberapa hal, yang diantaranya sebagai berikut, yaitu motivasi seseorang dalam memasuki pekerjaan, cara pandang seseorang terhadap pekerjaan, lingkungan pekerjaan, fasilitas dalam pekerjaan, ketenangan dan semangat kerja, tugas dan jabatan sesuai dengan kemampuan dan minatnya, kesempatan untuk berkarir, keamanan dan kenyamanan bekerja, rekan sekerja, kompensasi atau imbalan, kepribadian dan kehidupan emosional seseorang.

Dari uraian kerangka kerja pemikiran, dapat dirumuskan ke dalam bentuk hipotesis kerja penelitian yaitu, bahwa "Terdapat pengaruh sistem pembelajaran dan kepuasan kerja dosen terhadap kinerja dosen, baik secara parsial maupun secara simultan". Sub hipotesisnya adalah sebagai berikut:

$$
\mathrm{H}_{\mathrm{o}}=\mathrm{r}=0
$$

Tidak terdapat pengaruh yang positif dan signifikan antara sistem pembelajaran dan kepuasan kerja dosen terhadap kinerja dosen STIKes Karsa Husada Garut.

$\mathrm{H}_{1}=\mathrm{r} \neq 0$ Terdapat pengaruh yang positif dan signifikan antara sistem pembelajaran dan kepuasan kerja terhadap kinerja dosen STIKes Karsa Husada Garut.

\section{METODOLOGI PENELITIAN}

Metode penelitian yang digunakan adalah metode deskriptif analisis dan kausal riset. Metode deskriptif analisis adalah metode penelitian yang bertujuan untuk menggambarkan, menjelaskan keadaan tentang objek penelitian berdasarkan fakta dan data yang dikumpulkan kemudian disusun secara sistematis dan dianalisis untuk mendapatkan kesimpulan. Kausal riset berkaitan apabila kinerja dosen benarbenardipengaruhi olehsistem pembelajaran dan kepuasan kerja dosen di STIKes Karsa Husada Garut. Populasi dalam penelitian ini adalah dosen STIKes Karsa Husada Garut yang berjumlah 375 orang terdiri 50 orang dosen, 320 orang mahasiswa dan 5 orang penyelenggara pendidikan adalah bagian dari jumlah dan karakteristik yang dimiliki oleh populasi tersebut (Sugiyono, 2014).

Tabel 3

Populasi dan Sampel STIKes Karsa Husada Garut

\begin{tabular}{|c|c|c|c|}
\hline $2 n$ & Theicolsta & Fergiled & stry:A \\
\hline 1 & Mances & 53 & 43 \\
\hline 5 & 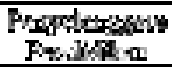 & 5 & 5 \\
\hline 3 & Wobsersa & inge & ti \\
\hline & Thenla: & 3\% & $F$ \\
\hline
\end{tabular}

\section{HASIL DAN PEMBAHASAN}

1. Pengaruh Sistem Pembelajaran (X1) dan Kepuasan Kerja Dosen (X2) Terhadap Kinerja Dosen(Y) 
Untuk menganalisis hubungan kausal (pengaruh) antara Sistem Pembelajaran dan Kepuasan Kerja Dosen terhadap Kinerja Dosen STIKes Karsa Husada Garut digunakan suatu metode analisis yang disebut dengan Analisis Jalur (Path Analysis). Langkahlangkah untuk membentuk struktur model analisis jalur adalah sebagai berikut:

a. Menghitung koefisien korelasi bivariat untuk setiap pasangan variabeleksogen $(X)$, dan variabel endogen (Y), hasilnya disusun dalam tabel dibawah ini.

Tabel 4

Matriks Korelasi Variabel Eksogen dan Endogen

\begin{tabular}{|c|c|c|c|}
\hline Variahel & $\mathbf{X}_{1}$ & $\mathbf{X}_{2}$ & $\mathbf{Y}$ \\
\hline $\mathbf{X}_{\mathbf{1}}$ & 1,000 & 0,600 & 0,750 \\
\hline $\mathbf{X}_{\mathbf{2}}$ & 0,600 & 1,000 & 0,652 \\
\hline $\mathbf{Y}$ & 0,750 & 0,652 & 1,000 \\
\hline & & & \\
\hline
\end{tabular}

b. Menyusun matriks korelasi antar variabel eksogen.

Tabel 5

Matriks Korelasi antar Variabel Eksogen

\begin{tabular}{|c|c|c|}
\hline Farbded & I. & $\mathbf{x}$ \\
\hline$x_{1}$ & $1,50 \%$ & $0,50 \%$ \\
\hline$\overline{8}$ & estikn & 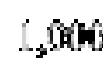 \\
\hline
\end{tabular}

c. Menghitung matriks invers dari matriks korelasi antar variabel eksogen.

Tabel 6

Invers Matriks Korelasi antar Variabel

Eksogen

\begin{tabular}{|c|c|c|}
\hline Y iathe & $\lambda_{u}$ & $\mathrm{v}$ \\
\hline$r_{1}$ & in: & $-11,23 \%$ \\
\hline $\bar{x}$. & -3535 & $1,500^{\circ}$ \\
\hline
\end{tabular}

d. Menghitung koefisien jalur dengan rumus.

$$
\begin{gathered}
r^{2} y x_{1} \\
\sum_{j=1}^{s}\left(r_{0} \cdot r x_{y} y\right. \\
\left.r_{y} x_{1}-\begin{array}{l}
0,606 \\
0,288
\end{array}\right]
\end{gathered}
$$

e. Menghitung koefisien determinasi variable Xi terhadap Y.

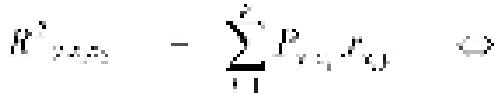

$$
\begin{aligned}
& R^{2},-0,660
\end{aligned}
$$

f. Menghitung koefisien determinasi, koefisien jalur variabel luar terhadap Y.

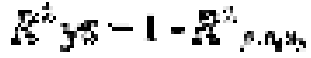

$$
\begin{aligned}
& \rightarrow F_{y}-\sqrt{1-F_{p}^{2}} \\
& \left.x^{2} \mathrm{y} a=1-0,500=0,3, t\right)
\end{aligned}
$$

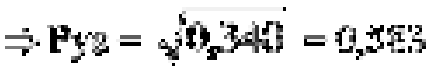

g. Menguji model jalur secara simultan menggunakan statistik uji F:

Hipotesis pengujian model struktural Kinerja Dosen:

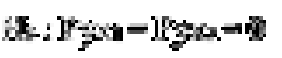

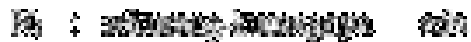
axts

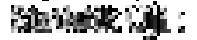
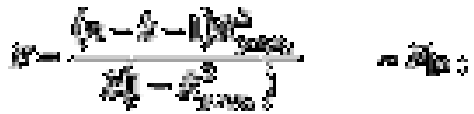

Foting

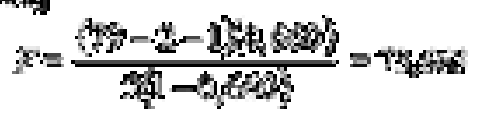

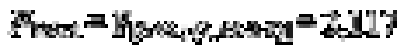

Kriteria uji: Tolak $\mathrm{H}_{0}$ jika $F>$ $F_{\text {tabel }}$

Karena $F_{\text {hitung }}=73,663>$ $F_{\text {tabel }}=3,117$ maka $\mathrm{H}_{0}$ ditolak, 
artinya sedikitnya ada sebuah jalur Sistem Pembelajaran dan atau Kepuasan Kerja Dosen yang memberikan pengaruh signifikan terhadap Kinerja Dosen. Dengan pengujian secara simultan menggunakan statistik uji $F$ tidak dapat diketahui variabel mana yang sebenarnya memberikan pengaruh yang signifikan terhadap model jalur Kinerja Dosen. Untuk itu selanjutnya akan diuji hipotesis untuk setiap koefisien jalur menggunakan statistik uji $t$ untuk mengetahui variabel yang berpengaruh terhadap Kinerja Dosen.

h. Menguji masing-masing koefisien jalur secara parsial.

$\mathrm{H}_{0}$ : Pyxi $=0$, secara parsial $\mathrm{Xi}$ tidak berpengaruh terhadap $\mathrm{Y}$.

$\mathrm{H}_{1}$ : Pyxi $>0$, secara parsial $\mathrm{Xi}$ berpengaruhterhadapY; $I=1,2$. Statistik Uji:

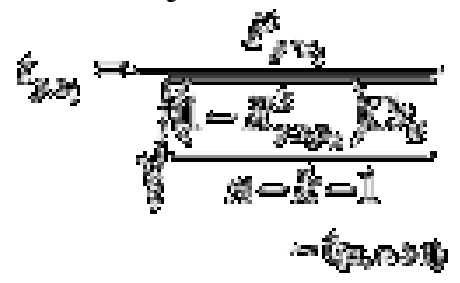

$\mathrm{Cr}_{\mathrm{ii}}=$ diagonal utama invers matriks korelasi antar variabel eksogen. Statistik uji secara parsial Sistem Pembelajaran dan Kepuasan Kerja Dosen terhadap Kinerja Dosen mengikuti sebaran distribusi $t$ student dengan derajat bebas $\mathrm{v}=\mathrm{n}-\mathrm{k}-1$. Penentuan penerimaan atau penolakan hipotesis pada taraf signifikansi $\alpha$ adalah dengan membandingkan statistik uji dengan nilai t tabel. Jika $|\mathrm{Nilai} \mathrm{T}|>\mathrm{t}_{\text {tabel }}$ maka hipotesis nol ditolak, artinya jalur dari Sistem Pembelajaran dan Kepuasan Kerja Dosen tersebut memberikan pengaruh yang signifikan terhadap Kinerja Dosen.

i. Uji Hipotesis Sistem Pembelajaran $\left(\mathrm{X}_{1}\right)$
Hipotesis yang diajukan untuk pengujian koefisien jalur dari variabel Sistem Pembelajaran terhadap Kinerja Dosen adalah:

$\mathrm{H}_{0}: \mathrm{Pyx}_{1}=0$, secara parsial $\mathrm{X} 1$ tidak berpengaruh terhadap Y.

Nilai uji:

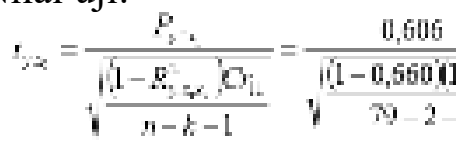

Kriteria uji: hipotesis nol ditolak apabila $t>t_{\text {tabel }}=1,992$, berdasarkan perhitungan di atas ternyata $t=7,241>1,992$, artinya hipotesis nol ditolak. Jadi dapat ditarik kesimpulan bahwa variabel Sistem Pembelajaran memberikan pengaruh positif terhadap Kinerja Dosen STIKes Karsa Husada Garut.

j. Uji Hipotesis Kepuasan Kerja Dosen $\left(\mathrm{X}_{2}\right)$

Hipotesis yang diajukan untuk pengujian koefisien jalur dari variabel Kepuasan Kerja Dosen terhadap Kinerja Dosen adalah:

$\mathrm{H}_{0}: \operatorname{Pyx}_{2}=0$, secara parsial $\mathrm{X}_{2}$ tidak berpengaruh terhadap $\mathrm{Y}$.

$\mathrm{H}_{1}$ : $\mathrm{Pyx}_{2}>0$, secara parsial $\mathrm{X} 2$ berpengaruh terhadap $\mathrm{Y}$.

Statistik uji:

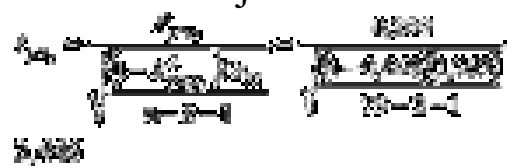

Kriteria uji: hipotesis nol ditolak apabila $t>t_{\text {tabel }}=1,992$, berdasarkan perhitungan diatas ternyata $t=3,446>1,992$, artinya hipotesis nol ditolak. Jadi dapat ditarik kesimpulan bahwa variabel Kepuasan Kerja Dosen memberikan pengaruh positif terhadap Kinerja Dosen STIKes Karsa Husada Garut. 
Dari urian uji hipotesis koefisien jalur secara parsial di atas dapat diringkas dalam sebuah tabel, seperti terlihat dalam table berikut ini.

\section{Tabel 7}

Ringakasan Pengujian Koefisien Jalur

\begin{tabular}{|c|c|c|c|c|c|c|}
\hline $\begin{array}{c}\text { Varia } \\
\text { bel }\end{array}$ & $\begin{array}{c}\text { Koe } \\
1 . \\
\text { Jal } \\
\text { ur }\end{array}$ & $\mathrm{Cr}_{\mathrm{a}}$ & $\begin{array}{l}\mathrm{Na} \\
\text { ai } t\end{array}$ & $t_{\text {tasil }}$ & $\begin{array}{c}\text { Kesimpo } \\
\text { Lan }\end{array}$ & $\begin{array}{l}\text { Keterau } \\
\text { gan }\end{array}$ \\
\hline$x_{1}$ & $\begin{array}{c}0,60 \\
6\end{array}$ & $\begin{array}{c}1,55 \\
3\end{array}$ & $\begin{array}{c}7,24 \\
1\end{array}$ & $\begin{array}{c}1,99 \\
2\end{array}$ & Tolak $\mathrm{He}$ & Ada jalur \\
\hline $\mathrm{X}_{2}$ & $\begin{array}{c}0,28 \\
8\end{array}$ & $\begin{array}{c}1,55 \\
3\end{array}$ & $\begin{array}{c}3,44 \\
6\end{array}$ & $\begin{array}{c}1,99 \\
2\end{array}$ & Tolak $\mathrm{H}_{e}$ & Ada jahur \\
\hline
\end{tabular}

Besaran-besaran yang telah dihitung, digambarkan dalam diagram jalur seperti terlihat dibawah ini.

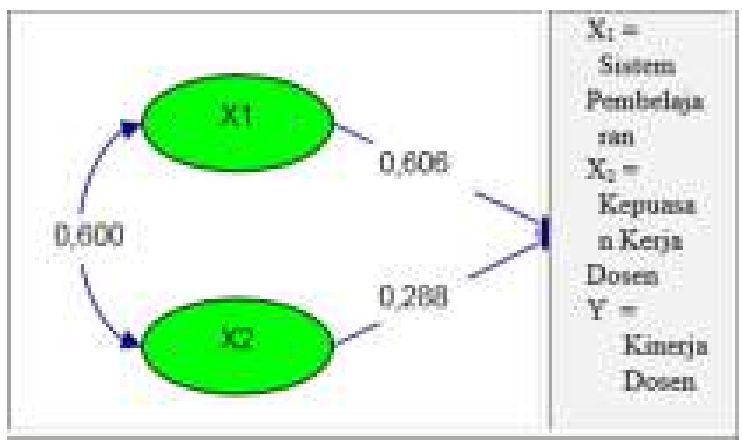

Gambar 1

Model Kinerja Dosen yang Dipengaruhi oleh Sistem Pembelajaran dan Kepuasan Kerja Dosen

Berdasarkan model jalur tersebut dapat diketahui bahwa semua koefisien jalur dari variabel Sistem Pembelajaran dan Kepuasan Kerja Dosen terhadap variabel Kinerja Dosen bertanda positif, artinya Sistem Pembelajaran dan Kepuasan Kerja Dosen baik secara simultan maupun secara parsial akan meningkatkan Kinerja Dosen. Pada model Kinerja Dosen ini, jika Sistem Pembelajaran meningkat satu satuan maka akan meningkatkan Kinerja Dosen sebesar 0,606 satuan. Begitu pula halnya dengan Kepuasan Kerja
Dosen akan meningkatkan Kinerja Dosen sebesar 0,288 satuan.

Semua variabel atau koefisien jalurnya signifikan, maka dapat dihitung besarnya persentase pengaruh untuk masing-masing variabel, tujuannya untuk mengetahui besarnya atau penurunan terhadap Kinerja Dosen. Cara menghitung pengaruh langsung dan tak langsung dari variabel eksogen terhadap variabel endogen adalah dengan memperhatikan nilai koefisien jalur dan nilai koefisien korelasi antar variable eksogen.

Pengaruh langsung $\mathrm{Xi}$ terhadap $\mathrm{Y}=\left(\mathrm{Pyx}_{\mathrm{i}}\right) \cdot\left(\mathrm{Pyx}_{\mathrm{i}}\right)$ Pengaruh tidak langsung $X_{i}$ melalui $\mathrm{X}_{\mathrm{j}}$ terhadap $\mathrm{Y}=$ (Pyxi).(rxixj).(Pyxj)

\section{Tabel 8}

Pengaruh Sistem Pembelajaran dan Kepuasan Kerja DosenTerhadap Kinerja Dosen

\begin{tabular}{|c|c|c|c|c|c|c|}
\hline \multirow{2}{*}{$\begin{array}{c}\text { Var } \\
\text { iabe } \\
1\end{array}$} & \multirow{2}{*}{$\begin{array}{c}\text { Koefi } \\
\text { sien } \\
\text { Jalar }\end{array}$} & \multirow{2}{*}{$\begin{array}{l}\text { Penga } \\
\text { rut } \\
\text { Langs } \\
\text { ung }\end{array}$} & \multicolumn{2}{|c|}{$\begin{array}{l}\text { Pengaruh } \\
\text { Tidak } \\
\text { Langsun } \\
\mathbf{g}\end{array}$} & \multirow[t]{2}{*}{$\begin{array}{l}\text { Total } \\
\text { PTL }\end{array}$} & \multirow[t]{2}{*}{$\begin{array}{l}\text { Sub. } \\
\text { Total }\end{array}$} \\
\hline & & & $\boldsymbol{X}_{1}$ & $\mathbf{X}_{2}$ & & \\
\hline $\mathbf{X}_{1}$ & 0,606 & 0,367 & & $\begin{array}{l}0,1 \\
05\end{array}$ & 0,105 & 0,472 \\
\hline $\mathbf{X}_{2}$ & 0,288 & 0,083 & $\begin{array}{l}0,1 \\
05\end{array}$ & & 0,105 & 0,188 \\
\hline \multicolumn{6}{|c|}{ Total Pengarvh } & 0,660 \\
\hline
\end{tabular}

2. Pengaruh Sistem Pembelajaran $\left(\mathrm{X}_{1}\right)$ Terhadap Kinerja Dosen (Y)

Perhitungan pengaruh langsung dan pengaruh tak langsung variabel Sistem Pembelajaran terhadap variabel Kinerja Dosen adalah sebagai berikut. 
Tabel 9

Persentase Pengaruh Sistem Pembelajar

\begin{tabular}{|c|c|c|}
\hline Testas & Eud Besstaste & os \\
\hline 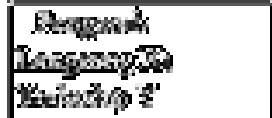 & Beose & zaini \\
\hline 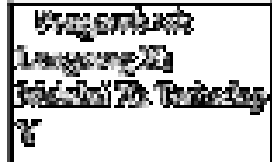 & 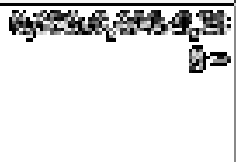 & 4as \\
\hline 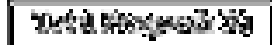 & $\infty$ & \\
\hline
\end{tabular}

Pengaruh langsung dari Sistem Pembelajaran terhadap Kinerja Dosen adalah sebesar $36,7 \%$, sedangkan pengaruh tak langsung Sistem Pembelajaran melalui Kepuasan Kerja Dosen adalah sebesar 10,5\%. Sehingga Total pengaruh Sistem Pembelajaran terhadap Kinerja Dosen adalah sebesar 47,2\%. Artinya dengan mempertimbangkan variabel Sistem Pembelajaran dalam model jalur akan meningkatkan Kinerja Dosen sebesar $47,2 \%$.

3. Pengaruh Kepuasan Kerja Dosen $\left(\mathrm{X}_{2}\right)$ Terhadap Kinerja Dosen (Y)

Dari hasil analisis untuk melihat hubungan kausal antara Sistem Pembelajaran dan Kepuasan Kerja Dosen terhadap Kinerja Dosen STIKes Karsa Husada Garut menggunakan Path Analysis, menunjukkan terdapat pengaruh positif dari variabel Sistem Pembelajaran dan Kepuasan Kerja Dosen terhadap Kinerja Dosen. Pengaruh terbesar diberikan oleh variabel Sistem Pembelajaran terhadap Kinerja Dosen yaitu sebesar 47,2\%, sementara itu Kepuasan Kerja Dosen memberikan pengaruh terhadap Kinerja Dosenhanya sebesar 18,8\%.

Besarnya pengaruh total dari variabel Sistem Pembelajaran dan Kepuasan Kerja Dosen terhadap model jalur Kinerja Dosen ditunjukkan oleh besarnya koefisien determinasi $\mathrm{R}^{2}=$ 0,660 atau sebesar $66,0 \%$, sedangkan pengaruh luar atau kekeliruannya sebesar $34,0 \%$. Dengan persentase koefisien determinasi model Kinerja Dosen yang lebih besar dari $60 \%$, maka dapat diambil kesimpulan bahwa model yang dibentuk termasuk dalam kategori cukup baik,sehingga dalam penelitian ini variabel Sistem Pembelajaran dan Kepuasan Kerja Dosen sudah cukup tepat digunakan untuk mengukur terhadap STIKes Karsa Husada Garut.

Telah dijelaskan dalam latar belakang masalah, bahwa penelitian ini mengungkapkan masalah sistem pembelajaran dan kepuasan kerja dosen terhadap kinerja dosen. Faktor yang dapat mempengaruhi kegiatan proses sistem pembelajaran dikelas. Dari hasil penelitian didapatkan hasil: Pengaruh sistem pembelajaran terhadap kinerja dosen pada STIKes Karsa Husada Garut sesuai hasil penelitian menunjukkan bahwa terdapat pengaruh langsung dan tidak langsung, dengan total pengaruh sebesar 47,2\%. Dan pengaruh kepuasan kerja dosen terhadap kinerja dosen pada STIKes Karsa Husada Garut sesuai hasil penelitian menunjukkan bahwa terdapat pengaruh langsung dan tidak langsung, dengan total pengaruh sebesar $18,8 \%$.

\section{E. SIMPULAN DAN SARAN}

Berdasarkan hasil observasi, penelitian dan pembahasan, maka penelitian tesis ini menunjukkan bahwa sistem pembelajaran pada STIKes Karsa Husada Garut, pada saat ini sesuai dengan tahapan sistem pembelajaran hasil penelitian termasuk dalam kategori sedang, hal ini ditunjukkan dari pernyataan responden mengenai memiliki media pembelajaran yang memadai.

Peran kepuasan kerja dosen pada STIKes Karsa Husada Garut., pada saat ini sesuai dengan tahapan kuantil hasil 
PEDAGOGIA : Jurnal Ilmu Pendidikan

penelitian termasuk dalam kategori sedang, hal ini terlihat dari item pernyataan adanya pengawasan yang baik dari kepala sekolah dan pengawas dan item mendapat kesempatan yang sama dalam promosi pegawai.

Kondisi kinerja dosen pada STIKes Karsa Husada Garut., pada saat ini sesuai dengan tahapan hasil penelitian termasuk dalam kategori sedang, hal ini terlihat dari item pernyataan menyelenggarakan penelitian sederhana untuk keperluan pengajaran.

Sehingga hasil penelitian secara kuantitatif dapat disimpulkan sebagai berikut:

1. Pengaruh sistem pembelajaran terhadap kinerja dosen pada STIKes Karsa Husada Garut sesuai hasil penelitian menunjukkan bahwa terdapat pengaruh langsung dan tidak langsung, dengan total pengaruh sebesar47,2\%;

2. Pengaruh kepuasan kerja dosen terhadap kinerja dosen pada STIKes Karsa Husada Garut sesuai hasil penelitian menunjukkan bahwa terdapat pengaruh langsung dan tidak langsung, dengan total pengaruh sebesar $18,8 \%$;

3. Besarnya pengaruh total dari variabel sistem pembelajaran dan kepuasan kerja dosen terhadap model struktural kinerja dosen ditunjukkan oleh besarnya koefisien determinasi $\mathrm{R}^{2}=0.660$ atau sebesar $66.0 \%$, sedangkan pengaruh luar atau kekeliruannya sebesar $34.0 \%$. Dengan persentase koefisien determinasi yang lebih besar dari $60 \%$, maka dapat diambil kesimpulan bahwa model yang dibentuk termasuk dalam kategori cukup baik, sehingga dalam penelitian ini variabel sistem pembelajaran dan kepuasan kerja dosen cukup tepat digunakan untuk mengukur kinerja dosen pada STIKes Karsa Husada Garut. Dengan demikian dapat dikatakan bahwa terdapat peranan yang cukup signifikan antara sistem pembelajaran dan kepuasan kerja dosen dalam meningkatkan kinerja dosen yang ditemukan dalam penelitian ini.

\section{DAFTAR PUSTAKA}

Dharma, Surya. (2013). Manajemen Kinerja; Falsafah Teori dan Penerapannya. Pustaka Pelajar. Yogyakarta.

E. Mulyasa (2008), Standar Kompetensi Dan Sertifikasi Guru. Bandung: Remaja Rosdakarya.

Edi S., Suwondo (2003). Guru di Indonesia. Jakarta: Dittendik Dirjen Dikdasmen

Edy Sutrisno, (2013). Manajemen Sumber Daya Manusia. Kharisma Putra Utama.

Hasibuan, Malayu S.P. (2003). Manajemen Sumber Daya Manusia. Jakarta: PT. Bumi Aksara.

Manajemen Sumber $\quad$ Daya Manusia (Edisi Revisi) .Jakarta: PT. Bumi Aksara.

Hornby (2004). Challenge and Change in the Information Society. London: Facet Pub.

Husein Umar (2003). Metode Penelitian Skripsi dan Thesis Bisnis. Jakarta: Raja Grafindo Persada.

Kuncoro, (2004). Metode Kuantitatif. Yogyakarta: UPP-AMPYKPN.

Lexy J. Moleong (2005). Metodologi Penelitian Kualitatif. Bandung: Remaja Rosdakarya.

M. Idochi Anwar dan Yayat Hidayat Amir (2002). Administrasi Pendidikan. Bandung: Alfabeta.

S. Nasution (2002). Berbagai Pendekatan dalam Proses Belajar dan Mengajar. Jakarta: Bumi Aksara. 
Riduwan (2006). Metode dan Teknik Menyusun Thesis. Bandung: Alfabeta.

Sudarwan Danim (2002). Inovasi Pendidikan: dalam upaya peningkatan profesionalise Tenaga Kependidikan. Bandung: Pustaka Setia.

Sugiono. (2004). Metode Penelitian. Bandung: Gramedia.

Undang-Undang No. 14 Tahun 2005 Tentang Guru dan Dosen. Keputusan Mendiknas No. 044/U/2002.

UU No.25 Tahun 2000 tentang Program Pembangunan Nasional (Propenas) 20002004.

Winardi. (2004). Motivasi dan pemotivasian dalam Manajemen. Jakarta: PT. Raja Grafindo Persada.

Weni (2004). Kontribusi Kemampuan Profesional dan Motivasi Kerja Guru terhadap Kinerja Mengajarnya pada SMA Negeri Di Kota Cimahi. 